OPEN ACCESS

Edited by:

Mitali Sarkar,

Chung-Ang University, South Korea

Reviewed by:

Bikash Koli Dey,

Hongik University, South Korea

Rekha Guchhait,

Yonsei University, South Korea

*Correspondence:

Florian Felix Stah

florian.klein@tum.de

Klaus Menrad

klaus.menrad@hswt.de

Specialty section:

This article was submitted to

Sustainable Supply Chain

Management

a section of the journal

Frontiers in Sustainability

Received: 01 November 2020 Accepted: 03 February 2021

Published: 02 March 2021

Citation:

Stahl FF, Emberger-Klein A and

Menrad K (2021) Consumer

Preferences in Germany for Bio-Based

Apparel With Low and Moderate

Prices, and the Influence of Specific

Factors in Distinguishing Between

These Groups.

Front. Sustain. 2:624913.

doi: 10.3389/frsus.2021.624913

\section{Consumer Preferences in Germany for Bio-Based Apparel With Low and Moderate Prices, and the Influence of Specific Factors in Distinguishing Between These Groups}

\author{
Florian Felix Stahl ${ }^{*}$, Agnes Emberger-Klein and Klaus Menrad* \\ Weihenstephan-Triesdorf University of Applied Sciences, Technical University of Munich Campus Straubing for Biotechnology \\ and Sustainability, Straubing, Germany
}

Bioplastics are a potential alternative to conventional plastics when it comes to reducing the use of the fossil resource of crude oil. There have been so far very few studies on the consumption of bio-based apparel and consumer preferences relating to it. Within this study, an online survey was conducted with 1,673 participants that is representative of the German population over the age of 16, including a choice-based consumer experiment with a bio-based rain jacket. Using latent class analysis, two clusters of consumers (39\% of respondents) were identified with acceptance of moderate prices for such bio-based products. The other $61 \%$ of consumers showed preferences for the lowest prices of the tested bio-based rain jacket. A discriminant analysis revealed that the intention to purchase bio-based apparel, the Green Consumer Value and subjective norms of bio-based apparel were the strongest significant factors when distinguishing between consumer groups of bio-based apparel with a "preference for a low price" and those showing "acceptance of a moderate price." This study helps to better illuminate the heterogeneity of consumer preferences for bio-based apparel related to pricing strategies and supports building up of a supply chain for such products.

Keywords: bio-based apparel, choice based conjoint analysis, consumer preference, environmental behavior, consumer studies, price, sustainable product

\section{INTRODUCTION}

The consumption of apparel has increased worldwide. A large proportion of apparel is made from conventional plastics, which causes substantial environmental problems, not least the fossil carbon dioxide footprint that is increasing every year (Textile Exchange, 2017; Chrobot et al., 2018; UNECE, 2018; UNFCCC, 2018; Šajn, 2019). This is why sustainable or green apparel is becoming a frequent topic of discussion as an alternative strategy that can help to protect the climate (Muthu, 2014; Balster, 2019; Klein, 2019). The global market for apparel is increasing steadily (Fashion United, 2017; CO Data, 2018; Šajn, 2019). In this context, Germany plays a leading role in Europe and produces more than $25 \%$ of all technical textiles (Euratex, 2019). Technical textile production is mainly based on crude oil. However, since petroleum is a fossil fuel and also the primary factor responsible for the heating of the earth's atmosphere, a more appropriate aim would be to dissolve 
the link between consumption and the use of fossil resources and to move over to using renewable resources. This includes plastics. In addition, plastic apparel enables the formation of a circular economy, as both conventional plastics and bio-based plastics used for textiles lend themselves to recycling (Textile Exchange, 2017). In order to mitigate the effects of carbon dioxide emissions on the atmosphere and instead store carbon in textiles by using plant material as a resource, it is essential that the manufactured garments are not fast fashion items and that they are suitable for frequent recycling (Muthu, 2014; Rana et al., 2014; Fuhr et al., 2019; Šajn, 2019). In addition, strategies are needed for preventing the release of microplastics during washing, such as using washing machine filters (Leinfelder and Regensburger, 2019).

So far, the market share of bio-based plastics in the textile sector is comparatively low, as the associated manufacturing industries are still in their development phase (Šajn, 2019). Up until now, there have only been few studies looking into consumer decisions, behavior and intentions regarding the consumption of green apparel or bio-based products (Hustvedt and Bernard, 2008; Hustvedt and Dickson, 2009; Niinimäki, 2010; Koszewska, 2013; Austgulen, 2016; Nam et al., 2017; Scherer et al., 2017, 2018a,b; Klein et al., 2019, 2020), even though consumer preferences and choices are an essential factor when it comes to developing innovative and sustainable products (Austgulen, 2016). Brand and Rausch (2020) found that very green consumers tended to prefer the influence of sustainabilityrelated attributes, such as materials, labels or country of origin, while price was by far the most influential driver for less green consumers when choosing bio-based outdoor apparel. Furthermore, Herbes et al. (2018) revealed that consumers are less concerned with renewable origins and almost not concerned at all with activities related to production, transportation and retail use. In a review, Joshi and Rahman (2015) found that consumer environmental awareness and the functional attributes of sustainable products emerged as the two most important determinants of consumers' green purchasing behavior. In addition, they summed up that a high price negatively influences the purchase intention and behavior of sustainable products. Lynch et al. (2017) revealed that acceptance and support for biobased technologies increases as consumers become more engaged with these technologies, and becomes even stronger when they identify opportunities for direct personal benefit. Additionally, Choi et al. (2020) show that U.S. consumers who care about environmentally friendly production and recycling practices are willing to pay a premium for bio-based batteries.

Additionally there are first hints in previous studies that consumer estimations differ with respect to pricing of bio-based products. Several studies found that the relevance of prices for product preferences of bio-based products differ between committed environmentally friendly consumers and those with less environmentally friendly attitudes (Kurka, 2012; Kainz, 2016; Scherer et al., 2018b). Hustvedt and Bernard (2008) also found that participants in an experimental auction displayed a greater willingness to pay for organic socks. Additionally, several studies showed an increase in utility of medium prices of bio-based products in particular for consumers with more environmentally friendly attitudes (Scherer et al., 2018b; Brand and Rausch, 2020, Niedermeier et al., 2021).

However, no recent studies have focused on differing consumer estimations related to price variations of bio-based products although the existing literature shows the high relevance of prices for purchasing of bio-based products (Hartmann and Apaolaza-Ibáñez, 2012; Joshi and Rahman, 2015; Chekima et al., 2016; Aschemann-Witzel and Zielke, 2017). Therefore, this study aims to contribute to this research area by analyzing the following research questions:

- Which consumer segments can be identified in terms of product pricing for bio-based apparel?

- What are the factors that influence consumers' price preferences for different bio-based apparel and play a role in distinguishing between different consumer groups?

This study aims to identify the potential heterogeneity of consumer perceptions regarding different prices of bio-based apparel, taking into account the associated environmental benefits. It also identifies those factors that play a significant role in distinguishing between different groups of bio-based apparel consumers, i.e., those with a "preference for a low price" and those with an "acceptance of a moderate price."

The paper provides information on the key predictors of consumers' green purchasing behavior toward green apparel. In this way, it will support policymakers and company managers in formulating and implementing strategies to promote purchasing of green products.

\section{FACTORS INFLUENCING CONSUMERS' PRICE PREFERENCES WITH BIO-BASED APPAREL}

This study investigates factors that influence consumers' price preferences relating to bio-based apparel. For this purpose, a review of the scientific literature was conducted to determine relevant variables relating to price preference and particular attributes of bio-based apparel. The following section therefore provides background information and defines the independent variables.

\section{Sociodemographic Variables: Age, Gender, Education}

Sociodemographic characteristics are often employed in consumer research studies, but their inflow toward green consumption tends to be low (Straughan and Roberts, 1999; Casimir and Dutilh, 2003; Diamantopoulos et al., 2003; Tanner and Wölfing Kast, 2003; Hess et al., 2013). Klein et al. (2019) showed a weak influence of sociodemographic factors on purchase intention of bio-based products what was supported by mixed results of Niedermeier et al. (2021). Due to the ambiguous results presented in the studies reviewed, it is assumed that sociodemographic characteristics (in this study represented by age, gender, and education) have no influence on price preferences relating to bio-based apparel. 


\begin{abstract}
Altruism
Altruism or prosocial behavior as defined by Batson and Powell (2003) can be a precursor to eco-friendly consumption. Evidence of this has been reported in several studies. For instance, Lusk et al. (2007) found that people who are more altruistic are willing to pay more for environmentally certified pork. Hefner (2013) identified altruism as one of the drivers of ecofriendly behavior. Straughan and Roberts (1999) also found a strong correlation between altruism and environmentally friendly consumer behavior. In addition, Stern et al. (1993) concluded that social altruism and environmentally friendly behavior are related (as measured by the predicted willingness to pay higher gas prices or income taxes). Teng et al. (2015) and Pfattheicher et al. (2016) showed that altruistic behavioral intentions are positively related to eco-friendly buying intentions. Hence, altruism is seen as a factor that determines consumers' willingness to purchase bio-based apparel and that influences them to accept higher prices for bio-based apparel.
\end{abstract}

\section{Subjective Norms of Bio-Based Apparel}

Individuals tend to behave in a particular way when they believe that they are expected to do so by certain people. These socalled subjective norms are an element of the theory of reasoned action proposed by Ajzen and Fishbein (1980). It is a wellknown influencing factor that is frequently used for measuring environmentally friendly behavior. For example, Teng et al. (2015) reported a positive influence of subjective norms on purchase intentions for green products. In addition, several other studies have demonstrated the influence of subjective norms (Tarkiainen and Sundqvist, 2005; Hefner, 2013; Mishra et al., 2014; Untaru et al., 2016). Nam et al. (2017) found that subjective norms relating to green sportswear had a positive impact on the intention to purchase green sportswear. This is supported by Klein et al. (2019) who showed that subjective norms increase the purchase intention of bio-based products. Based on the previous findings it is assumed, if subjective norms have a stronger influence, consumers will tend to accept a moderately higher price for bio-based apparel.

\section{Innovativeness}

The power of consumers to be innovative, as discussed by Tellis et al. (2009) is an important driver in the introduction of environmentally friendly product innovations (Jansson, 2011; Englis and Phillips, 2013). Osburg et al. (2016) found that the likelihood of a consumer choosing wood-plastic composites over conventional plastics correlates with the consumer's innovativeness. In addition, Scherer et al. (2017) noted that ecologically sensitive consumers are more innovative than consumers of conventional plastic. Klein et al. (2020) showed that more innovative consumers are more in favor of biobased products. Therefore, an individual's interest in innovation seems to have a positive impact on their decision to purchase eco-friendly apparel. Thus, it is claimed that a higher level of consumer innovativeness leads to increased acceptance of a moderate price for bio-based apparel.

\section{Green Consumer Values (GCV)}

Haws et al. (2014) developed a set of environmental conservation attitudes and values with which to examine the relationship between an individual's green values and his or her eco-friendly purchasing decisions. They found evidence of a correlation between GCV and consumer buying intentions for green products. This was also reported for similar items by Kurka (2012) and Scherer et al. (2017). Niedermeier et al. (2021) showed that GCV act as a driver for purchase of bio-based products. Furthermore, GCV can be used to significantly separate green consumer segments from others in relation to bio-based products (Niedermeier et al., 2021). Therefore, it is assumed that increasing GCV would also affect consumers' acceptance of moderate prices for bio-based apparel.

\section{Attitude Toward Bioplastics}

Hartmann and Apaolaza-Ibáñez (2012) and Teng et al. (2015) have shown that consumers' concern for the environment has a positive impact on their intention to purchase green products. Recent studies by Rumm et al. (2013), Rumm (2016), and Scherer et al. (2017) also found a link between environmental attitudes and choice-based behavior with regard to bio-based products. Klein et al. (2019) found a strong influence of attitudes toward bioplastics on the purchase intention of bio-based products. Based on these findings is assumed that an attitude of increased acceptance toward bioplastics affects consumers' willingness to accept moderate prices for bio-based apparel.

\section{Product Experience Made With Bio-Based Products}

Lee et al. (1995) and Young (2000) claimed that past recycling behavior evolves into future recycling behavior. Further evidence of the impact of product experience on purchase intent with green products has been provided by Young et al. (2009). Blesin et al. (2017) showed that past product experience leads to a greater purchase intention for bio-based products. Additionally, Klein et al. $(2019,2020)$ showed that previous product experiences increase the probability of purchasing bio-based products. Therefore, previous consumer behavior is expected to affect consumers' acceptance of moderate prices for bio-based apparel.

\section{Interest in Bioplastics}

Rumm et al. (2013) and Schleenbecker and Hamm (2013) found that product and resource information has a positive impact on both green products themselves and the decision to purchase them. Similarly, McDonald et al. (2009) found that green consumers seek out information about sustainable products. Klein et al. (2019) showed that more interest in bioplastics significantly increases the purchase intention of biobased products. Thus, it is claimed that a higher influence of interest in bioplastics leads to consumers accepting a moderate price for bio-based apparel.

\section{Purchase Intention}

The intention to buy environmentally friendly products can be regarded as a form of behavioral purpose, which refers to the 
subjective ability of an individual to engage in behavior. This can be influenced by behavioral attitudes (Ajzen and Fishbein, 1980). Morrison (1979) showed that purchase intent predicts buying behavior. Green consumption has been analyzed in previous studies on the basis of purchase intent (Laroche et al., 2001; Hartmann and Apaolaza-Ibáñez, 2012; Nam et al., 2017). In line with these studies, it is assumed that purchase intention is a relevant influencing factor toward consumers' acceptance of moderate prices for bio-based apparel.

Altogether, a broad range of studies can be identified that have dealt with factors that influence consumers' price preferences for green or bio-based products (Table 1). However, most of these studies only consider single items in this context, so that there is need for a comprehensive study in this area of research.

\section{METHODS}

\section{Data}

The data was collected in June 2016 by a professional market research company that was commissioned to recruit respondents through an online access panel. Participants received little financial incentive to complete the full survey. Web surveys are cheaper than other survey methods and enable faster data collection (Evans and Mathur, 2005). The representative group of the German population over the age of 16 was based on the sociodemographic characteristics as indicated by the German sample survey 2015 (German Federal Statistical Office, 2015). The quotas were determined by gender, age, education and population of the city of residence (Table 2). Once the data was collected, the data was purged relating to unworkable responses (straightliners, Christmas tree behavior, conflicting answers, incorrectly answered test questions, etc.). After statistical evaluation, there remained 1,673 respondents. Further data management and analysis were performed using Sawtooth 8 (Sawtooth Software Inc., 2015) and SPSS 23 (IBM Corp., 2015). The independent variables and covariates used in the $\mathrm{CBC}$ analysis, the latent class analysis and the discriminant analysis were derived from the literature review. They were mainly measured on the basis of 5point Likert scales. All the factors and variables used are listed in Table 4.

\section{Choice Based Conjoint Analysis}

Choice-based Conjoint Analysis (CBC) is a widely used and valid method of examining preferences for either innovative or existing products (Eggers and Sattler, 2011; Louviere and Woodworth, 2018). Although the decisions measured do not necessarily result in purchasing behavior, they shed light on the purchasing motivation for certain products, for example, on the basis of important properties that consumer products offer as well as the willingness of consumers to pay. In this sense, CBC experiments are able to simulate purchase situations of existing and in particular new products. A respondent's preference is based on the product concepts chosen in the CBC. A set of attributes with realistic and existing occurrences (levels) is selected (Table 3). The product concepts are either constructed randomly (random tasks) or chosen selectively (fixed tasks). The defined tasks form part of the validation of the method. The respondents rate each attribute level by selecting the depicted product concepts. The utility function is used to translate decisions made into the consumer's perceived preferences and to predict buying decisions (Eggers and Sattler, 2011). CBC analysis is based on the random utility theory of McFadden (1986). The random utility model considers two parts to utility $U$ in choice situation $i$ of a choice set $C_{q}$, the deterministic part of utility $V_{q i}$ and the random part of utility $\varepsilon_{q i}(1)$.

$$
U_{q i}=V_{q i}+\varepsilon_{q i}
$$

\section{Attributes and Levels, Product-Concepts}

$\mathrm{CBC}$ experiments require a set of attributes with different levels, for implementation of the product concepts created. In a CBC analysis, attributes are sources of utility because the level of utility for a respondent depends on the level of attributes. The contribution of a particular attribute to the total utility of an alternative is called "part-worth." As utility is an ordinal concept and the relative utility compared to alternatives in the same choice set is of interest, the reference utility is used in this study.

In this study, attributes were considered that either already exist or can potentially play a role in the German market. The attributes and levels were defined on the basis of an expert interview, market analysis and literature review (Table 3). Thereby, the attribute levels were located in terms of the percentage of bioplastic in fabric in the market for rain jackets in $2016(20 \%)$ or assumed that higher percentages of bioplastics might potentially be of importance to consumers $(50,100 \%)$. The biogenic resources shown in the $\mathrm{CBC}$ contain substances/compounds that can be used to manufacture bioplastics for textile usage. Sanad (2016) found that the origin of the apparel is of relevance to consumers. The attribute levels in terms of origin of resource were selected in accordance with the potential location of crop cultivation. According to Borin et al. (2011) and Chekima et al. (2016) eco-labels or certificates are of value to consumers in that they serve to create product trust, communicate certain properties of a product, and promoting the purchase of green products. Therefore, three certificate types familiar from the German market were included in the CBC design. The prices chosen for the $\mathrm{CBC}$ display a wide range of $69 €$ to $349 €$. However, this price range is realistic for the German market for functional rain jackets for outdoor usage. Respondents were also able to select the option "None", see Appendices. This is interpreted as the choice threshold, as it means that the respondents preferred none of the three product concepts listed. The "None" option formed part of every choice set and represented the influence on utility of not choosing a product.

\section{Relevant Factors Influencing Consumers' Price Preferences for Bio-Based Products}

The relevant factors were determined by way of an extensive literature review, as presented in section Factors Influencing Consumers' Price Preferences With Bio-Based Apparel. The factors were measured with validated scales used in previous studies, reformulated as necessary for the purpose of this study (Table 4). 
TABLE 1 | Overview of analysis of influencing factors on consumers' price preferences for purchasing green products.

References

Socio-demographic

Altruism Subjective norm of Innovativeness Green consumer Attitudes toward Product experience

Interest in Purchase

variables (age, gender,

bio-based apparel

values

bioplastics

with bio-based education)

Blesin et al. (2017)

Casimir and Dutilh (2003)

$x$

Diamantopoulos et al. (2003)

Englis and Phillips (2013)

Hartmann and Apaolaza-Ibáñez (2012

Haws et al. (2014)

Hefner (2013)

Hess et al. (2013)

Jansson (2011)

Klein et al. (2019)

Klein et al. (2020)

Kurka (2012)

Laroche et al. (2001)

Lee et al. (1995)

Lusk et al. (2007)

McDonald et al. (2009)

Mishra et al. (2014)

Morrison (1979)

Nam et al. (2017)

Niedermeier et al. (2021)

Niedermeier et al. (2021)

Osburg et al. (2016)

Pfattheicher et al. (2016)

Rumm et al. (2013)

Rumm (2016)

Scherer et al. (2017)

Schleenbecker and Hamm (2013)

Straughan and Roberts (1999)

Stern et al. (1993)

Tanner and Wölfing Kast (2003)

Tarkiainen and Sundqvist (2005)

Tellis et al. (2009)

Teng et al. (2015

Untaru et al. (2016)

Young (2000)

Young et al. (2009)

This study

$x$

$x$

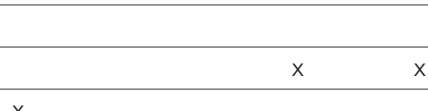

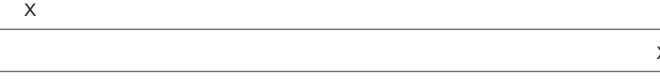

$x$

$x$

$x$

$x$

$x+\frac{x}{x}$


TABLE 2 | Sociodemographic data of the sample.

\begin{tabular}{|c|c|c|}
\hline Variable & Sample & $\begin{array}{c}\text { Population of Germany } \\
\text { 16+ } \\
\text { German Federal } \\
\text { Statistical Office, } 2015\end{array}$ \\
\hline \multicolumn{3}{|l|}{ AGE } \\
\hline $16-19$ years & 0.050 & 0.046 \\
\hline 20-29 years & 0.127 & 0.141 \\
\hline 30-39 years & 0.124 & 0.141 \\
\hline 40-49 years & 0.166 & 0.180 \\
\hline 50-59 years & 0.185 & 0.180 \\
\hline $60+$ years & 0.348 & 0.312 \\
\hline \multicolumn{3}{|l|}{ SEX } \\
\hline Female & 0.519 & 0.513 \\
\hline Male & 0.481 & 0.487 \\
\hline \multicolumn{3}{|l|}{ EDUCATION } \\
\hline Not yet graduated & 0.025 & 0.025 \\
\hline $\begin{array}{l}\text { Secondary modern school without } \\
\text { apprenticeship }\end{array}$ & 0.071 & 0.079 \\
\hline $\begin{array}{l}\text { Secondary modern school with } \\
\text { apprenticeship }\end{array}$ & 0.320 & 0.306 \\
\hline $\begin{array}{l}\text { General certificate of secondary } \\
\text { education }\end{array}$ & 0.298 & 0.303 \\
\hline $\begin{array}{l}\text { General qualification for University } \\
\text { entrance }\end{array}$ & 0.127 & 0.131 \\
\hline Academic studies & 0.160 & 0.157 \\
\hline
\end{tabular}

The same sample was used in the studies of Klein et al. $(2019,2020)$ but with different study objectives and methods.

\section{Segmentation of Consumers Using Latent Class Analysis}

Segment-specific parameters are estimated in the latent class model. This allows heterogeneous reactions of respondents to explanatory variables, such as price to be modeled (Temme, 2009). This results in the following utility function for each $k=$ $1, \ldots, M$ segment (2):

$$
U_{i k n}=X_{i n} \beta_{k}+e_{i k n}
$$

By integrating the extreme value distributed disturbance term, the conditional selection probability for each segment $\mathrm{k}$ is obtained (3) (Temme, 2009).

$$
P_{n}(i \mid k)=\frac{e^{V_{k i n}}}{\sum_{i} e^{V_{k j n}}}
$$

A latent class analysis based on a maximum likelihood estimation was performed with Sawtooth 8 to calculate clusters within the sample for the purpose of dividing consumers into heterogeneous classes based on their preferences for certain product attributes (Sawtooth Software Inc., 2004). At the beginning of the estimation process, the utility values for each segment were determined randomly. Afterwards, the data from each respondent was compared with the utility values of each segment and the probabilities of each respondent
TABLE 3 | Attributes and levels of the choice-based conjoint analysis.

\begin{tabular}{ll}
\hline Attributes & Levels \\
\hline Percentage of bioplastic in fabric & $100 \%$ \\
& $50 \%$ \\
Biogenic resource & $20 \%$ \\
& Potatoes \\
& Woodchip \\
& Sugar cane \\
Origin of resource & Maize \\
& South America \\
& European Union \\
Product certificate & United States of America \\
& Asia \\
Price & Free of pollutants \\
& Climate protection \\
& Fair production \\
& No certificate \\
& $349 €$ \\
& $239 €$ \\
& $109 €$ \\
& $69 €$ \\
& \\
&
\end{tabular}

The CBC setting was also used in the study of Klein et al. (2020) but with different study objectives and analyzing methods.

belonging to each segment calculated, while utility values and group affiliations were iteratively improved. The clustering was estimated with different group solutions. The best group solution was chosen by an appropriate Consistent Akaike Information Criterion (CAIC) and an appropriate relative Chi-square. Group size and coherence were also considered (Sawtooth Software Inc., 2004).

\section{Classification Through Discriminant Analysis}

Discriminant analysis is a method of classifying a dependent variable by the independent variables; it enables the study of two or more groups (Backhaus et al., 2000). The discriminant function $Y$ gives information about the optimal separation between the groups and allows to test the discriminatory significance (discriminant coefficients of the feature variables $b_{j}$ ) of the feature variable $X_{J}(4)$.

$$
Y=b_{0}+b_{1} X_{1}+b_{2} X_{2}+\ldots+b_{J} X_{J}
$$

In this study, the variables were identified that distinguished respondents who either indicated high part-worth utility values for low prices, respectively moderate prices for bio-based apparel. Respondents were divided into two group clusters based on the results of the latent class analysis. All six groups of latent-class analysis were thus scrutinized to determine values of relative importance and values of part-worth utilities within the latentclass analysis,. It was found that the latent class analysis segments A, D, E, and F all had the highest significance with regard to the importance of price, and the utility values within the price 
TABLE 4 | Constructs of the survey.

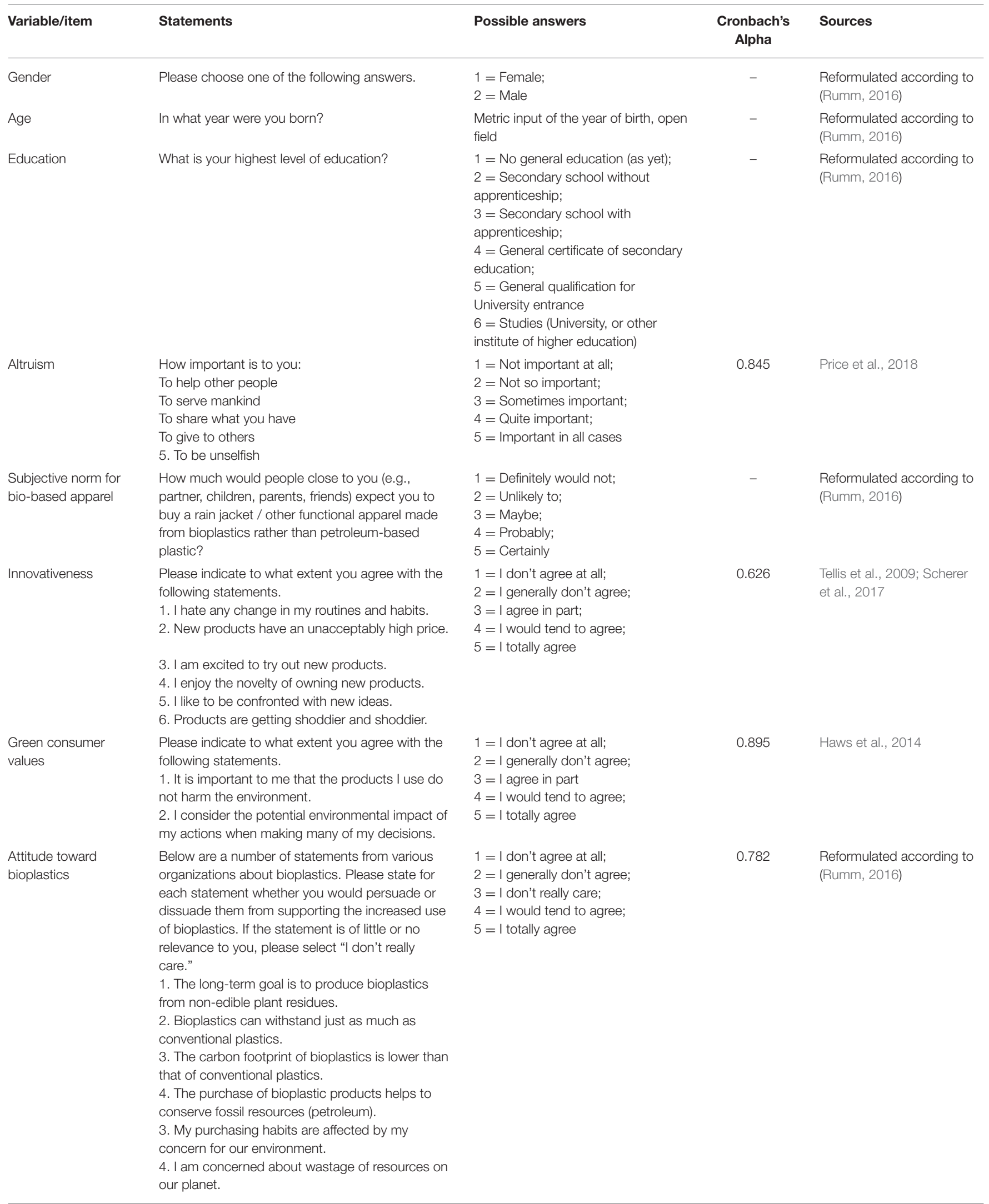


TABLE 4 | Continued

\begin{tabular}{|c|c|c|c|c|}
\hline Variable/item & Statements & Possible answers & $\begin{array}{l}\text { Cronbach's } \\
\text { Alpha }\end{array}$ & Sources \\
\hline & $\begin{array}{l}\text { 5. I would describe myself as environmentally } \\
\text { responsible. } \\
\text { 6. I am willing to accept inconvenience in order to } \\
\text { take actions that are more environmentally friendly. }\end{array}$ & & & \\
\hline $\begin{array}{l}\text { Product experience } \\
\text { with bioplastics }\end{array}$ & $\begin{array}{l}\text { Have you ever deliberately opted for bioplastics in } \\
\text { products? }\end{array}$ & $\begin{array}{l}0=\text { No; } \\
1=\text { Yes }\end{array}$ & - & $\begin{array}{l}\text { Reformulated according } \\
\text { (Rumm, 2016; Scherer } \\
\text { et al., 2018b) }\end{array}$ \\
\hline Interest in bioplastics & $\begin{array}{l}\text { Overall, are you interested in bioplastics in } \\
\text { general? }\end{array}$ & $\begin{array}{l}1=I \text { am not interested at all; } \\
2=1 \text { am not so interested; } \\
3=1 \text { could be interested; } \\
4=1 \text { am a little interested; } \\
5=1 \text { am very interested }\end{array}$ & - & $\begin{array}{l}\text { Reformulated according to } \\
\text { (Rumm, 2016) }\end{array}$ \\
\hline $\begin{array}{l}\text { Purchase intention for } \\
\text { bio-based products }\end{array}$ & $\begin{array}{l}\text { How will you decide in future purchase situations? } \\
\text { 1. I will consciously pay attention to bioplastic } \\
\text { products made of renewable resources in future } \\
\text { purchase decisions. } \\
2 \text {. When I have the choice between a plastic } \\
\text { product made of conventional materials and one } \\
\text { made of renewable raw materials in the future, I } \\
\text { will choose the one made of renewable } \\
\text { raw materials. }\end{array}$ & $\begin{array}{l}1=\text { Definitely not; } \\
2=\text { Not really; } \\
3=\text { Maybe; } \\
4=\text { Probably; } \\
5=\text { Certainly }\end{array}$ & 0.816 & Buxel, 2010; Rumm, 2016 \\
\hline
\end{tabular}

Some of the variables were also used in the studies of Klein et al. $(2019,2020)$ but with different study objectives and methods.

attribute-levels had the highest values for the lowest price level. Groups B and C neither showed their highest importance for the price, nor did they show the highest utilities at the lowest price level but for the moderate price level (see Table 5). Therefore, two aggregated consumer groups were formed separating those consumers showing clear preferences for a low price of a biobased product and those showing acceptance of a moderate price for such products. Finally, a discriminant analysis was used to investigate those factors that were able to distinguish between these two groups.

\section{RESULTS}

The results of the different statistical analysis steps are shown in the following two paragraphs.

\section{Consumer Segmentation Using Latent Class Analysis}

A latent class analysis of the $\mathrm{CBC}$ experiment data was used to for consumer segmentation that was performed in two to ten groups. The six-group solution was chosen because it had a comparatively well-fitting CAIC value $(24,975.22)$ and related chi-squared value (138.22). Table 5 shows the average importance of each attribute together with the part-worth utilities of the attribute levels for the identified six consumer clusters. Cluster A aggregates respondents for whom price is of high importance. The "None" option displays a high negative partworth utility, which strongly indicates that respondents of this cluster would rather choose functional clothes made of bioplastic, although other attributes apart from price revealed relatively low importance values. Cluster B aggregates respondents attributing moderate importance to price and relatively high importance to the origin of the biogenic resource. This cluster has the highest part-worth utility for a price of $109 €$, with woodchip produced in the EU as the preferable biomass. Respondents of cluster $\mathrm{C}$ show a higher preference for certified functional bioplastic apparel and a moderate importance assigned to price as well. They also display the highest utility for a price of $109 €$ and express a strongly negative part-worth utility for the "None" option. The clusters D, $\mathrm{E}$, and $\mathrm{F}$ all indicate a high price importance, and all show a strong preference for the lowest price of the rain jacket as well as positive part-worth utilities for the "None" option. Smaller differences can be found between clusters $\mathrm{D}, \mathrm{E}$ and $\mathrm{F}$, particularly in relation to the evaluation of the plant origin or the location of production of the biogenic resource.

\section{Influence of Independent Variables on Group Segmentation}

Preferences for bio-based apparel were investigated by the CBC, and respondents were segmented through a latent class analysis. A preference for low-price products was apparent in the clusters $\mathrm{A}, \mathrm{D}, \mathrm{E}$, and $\mathrm{F}$, while in the two clusters $\mathrm{B}$ and $\mathrm{C}$, respondents indicated lower utilities for the lowest price and preferred the price of $109 €$ for the rain jacket (Table 6). The respective clusters were aggregated for further analysis into two classes, with a distinction made between the groups indicating a "preference for a low price" and "acceptance of a moderate price." A discriminant analysis was conducted to determine the influence of different influencing factors on price preferences in these two groups. The test parameters of the discriminant function analysis reveal low separation by the variables, as indicated by a Wilks' Lambda of 0.919. Still, the groups can be separated with a probability of 
TABLE 5 | Clusters of the latent class analysis.

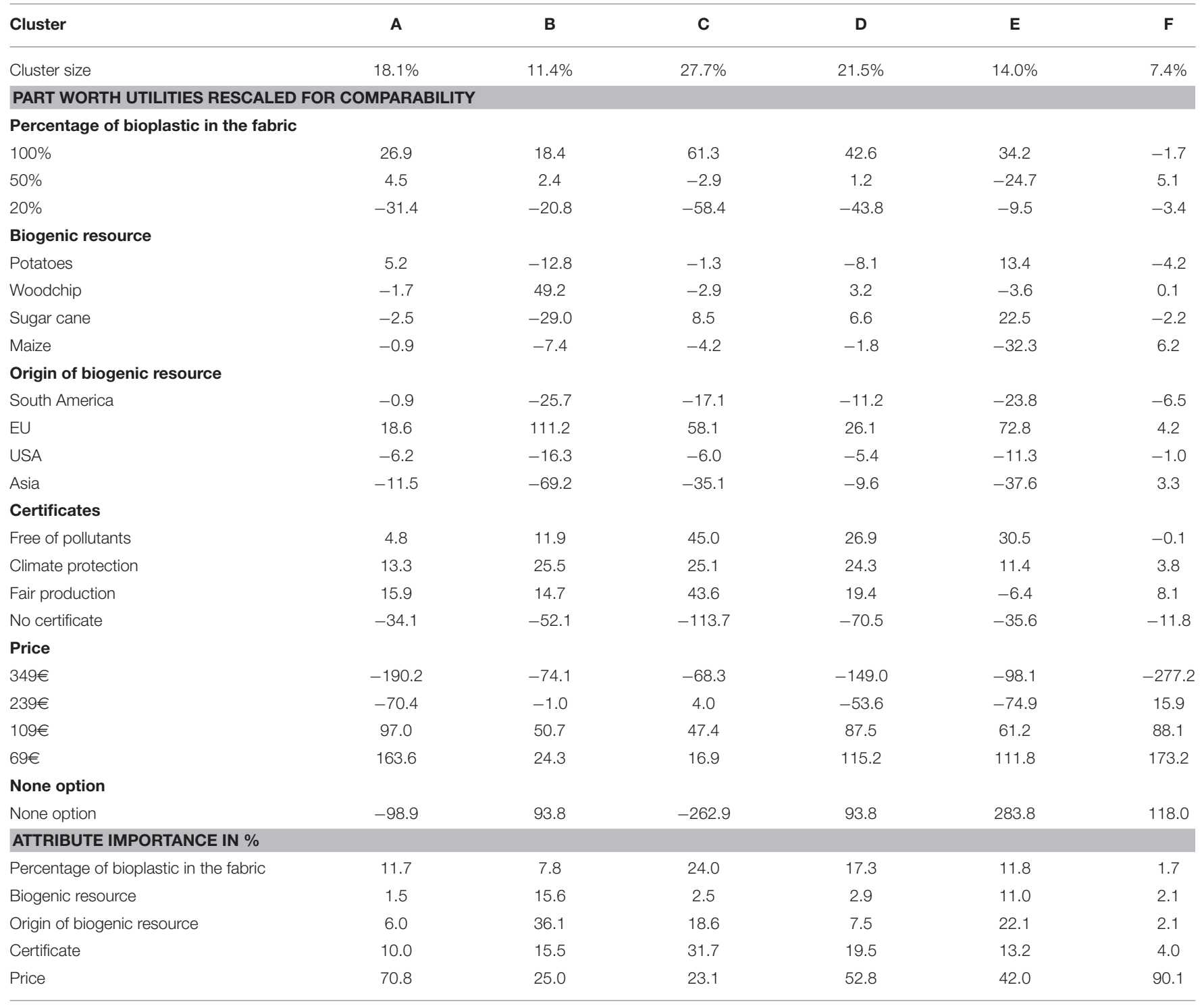

TABLE 6 | Structure matrix of discriminant analysis.

\begin{tabular}{|c|c|c|c|c|}
\hline Independent variables & Wilks-Lambda & $\boldsymbol{F}$ & Significance & Function \\
\hline Purchase intention for bio-based products & 0.948 & 90.768 & $0.000^{*}$ & 0.787 \\
\hline Green consumer values & 0.964 & 61.517 & $0.000^{*}$ & 0.648 \\
\hline Subjective norms of bio-based apparel & 0.966 & 59.374 & $0.000^{\star}$ & 0.637 \\
\hline Innovativeness & 0.974 & 43.936 & $0.000^{*}$ & 0.548 \\
\hline Altruism & 0.975 & 43.425 & $0.000^{*}$ & 0.544 \\
\hline Interest in bioplastics & 0.986 & 23.888 & $0.000^{*}$ & 0.304 \\
\hline Age & 0.999 & 2.069 & 0.151 & 0.119 \\
\hline Gender & 0.999 & 2.043 & 0.153 & 0.118 \\
\hline Education & 1.000 & 0.700 & 0.403 & 0.069 \\
\hline
\end{tabular}

${ }^{*}$ Significant at $99.9 \%$ level $(p<0.001)$. 
error of 0.0001 , checked by the chi-square test that is highly significant. The structure matrix shown in Table 6 describes the contribution of the independent variables to the separation of the two groups, starting with the variable with the strongest group-separating effect, as well as their significance in the separability of the two groups. The sociodemographic variables show no significant contribution to the discrimination, whereas all other variables are significant to the differentiation between the two price preference groups. Related to the strength of the separation effect, the purchase intention for bio-based apparel is the strongest separating variable, followed by GCV and subjective norms of bio-based apparel, whereas interest in bioplastics, attitudes toward bioplastics and previous product experience reveals weaker but still statistically highly significant effects.

\section{DISCUSSION AND CONCLUSIONS}

\section{Main Findings of the Study}

The first target of this study was to identify different consumer segments with differing preferences for product pricing for biobased apparel. On the one hand, two clusters of consumers were identified including $39 \%$ of respondents with acceptance of moderate prices for bio-based products. Scherer et al. (2018b) found similar effects, whereby the attributes "contains bio-based plastic" and "of vegetable oil origin" or "contains softeners" showed higher average importance values than the "price" attribute. Hustvedt and Bernard (2008) showed that participants in an experimental auction were willing to pay more for socks made of organic fibers, which can be regarded as a green attribute and is comparable to the "percentage of bioplastic in the fabric" attribute in this study. On the other hand, four clusters of consumers were discovered that have clear preferences for low prices of bio-based products. These consumers accounted for $61 \%$ of the respondents. Kurka (2012) found similar results, showing that participants who preferred non-bio-based plastics also preferred low prices.

Another aim of this study was to determine relevant influencing factors for the price preference of bio-based apparel. In this context the important separating variables were identified characterizing the two groups. The variables GCV, purchase intention for bio-based products, and subjective norm bio-based apparel were found to be the most suitable for separating the two groups into those with a "preference for a low price" and those showing "acceptance of a moderate price." In this context, Scherer et al. (2018b) conclude that GCV plays a major role in separating the classes of consumers who are interested in biobased products from those who are not. Innovativeness, altruism, product experience with bio-based products and attitude toward bioplastic are variables with a comparatively moderate influence on distinguishing between the groups. Scherer et al. (2018b) also found that innovativeness had an influence on the separation of consumers into those interested and those not interested in biobased products, although in the same study, no influence could be determined by product experience with bio-based products. Hustvedt and Dickson (2009) could not find that altruistic behavioral beliefs differed between two segments of organic cotton apparel consumers, but they did find an influence of environmental and apparel attitudes on separation of consumers. The high relevance of GCV for separating between different consumer types of bio-based products is also supported by Niedermeier et al. (2021). The same is true in case of subjective norms related to bio-based apparel in the study of Klein et al. (2019).

Interest in bioplastics reveals a comparatively low significant influence toward the separation of price preference classes. A general interest in bio-based products was also found in previous studies by Yue et al. (2010), Kurka (2012), Behe et al. (2013), and Kainz (2016). As in studies by Diamantopoulos et al. (2003), Tanner and Wölfing Kast (2003), Hess et al. (2013), Klein et al. (2019), and Niedermeier et al. (2021), this study has shown as well that socio-demographic characteristics have no relevance in the separation of the defined consumer groups.

\section{Limitations of the Study}

As with all empirical investigations, this study also has its weaknesses. A familiar weakness of surveys on environmental issues is that respondents' answers can be biased by social desirability (Grimm, 2010), and this cannot be ruled out here either. However, there are indications from Kaiser et al. (1999) and Milfont (2009) which suggest that the results of surveys are still representative, the aspect of social desirability notwithstanding.

Within the limited frame, budget and time of this study, it was not feasible to test all potential separation variables. It is therefore possible, that previously less prominent variables might have a greater influence than assumed. However, the selection was based on an extensive literature review, in which variables were found to be highly relevant for these purposes. In addition, such product attributes and levels were chosen within the $\mathrm{CBC}$ experiment that gave a realistic view of existing and emerging products that may possibly rise in importance in the future. Nevertheless, it is hardly possible to consider all product attributes in a $\mathrm{CBC}$.

Furthermore, the number of levels may have an effect, as not all attributes had the same amount of levels within the CBC. This can cause a bias in the estimation of relative importance, whereas attributes with more levels could result in an artificially higher estimate (Eggers and Sattler, 2011). However, in this case, only the attribute "percentage of bioplastic in the fabric" was set with fewer levels. The consequence of this would be that all other attributes would be overestimated or the opposite "percentage of bioplastic in the fabric" would be underestimated. The level of error that affects the relative importance of the price attribute can therefore be considered very low or non-existent.

This study was conducted in Germany and is representative of the population of this country. Other countries might have different socio-economic conditions, so it is important to carry out comparative studies and to check transferability to other societies. The same applies to transferability to apparel in general; this study concerned an outdoor rain jacket, and whether the same influencing factors also apply to other garments with environmental benefits needs to be investigated.

Although the discriminant analysis separation is validated as significant, Wilk's-Lambda shows a low discriminant function separation force. This may be due to the low separating force of 
the independent variables vs. the dependent variable. However, it is much more likely that it is because consumers are not yet able to accurately assess the product and its attributes because they still lack experience with bio-based apparel. Only when consumers have formed precise preferences can this be reflected in their price preference. Until the market for bio-based apparel has undergone further development, future research will be needed to reveal more sensitive factors for the classification of price preference toward bio-based apparel or to further test and compare the factors used in this study.

\section{Conclusions}

This study contributes further insights toward the understanding of consumer decisions in the context of bio-based apparel. In addition to assessing the relevance of the attributes and influencing variables, the focus of this study was on the significance of price preference. Since products always have different attributes, it is important to understand the relevance of the products and the psychographic characteristics of consumers and, if necessary, to link them to a price perception. In this way, companies are also able to understand the economic relevance of various attributes. Furthermore, a CBC does not represent a study of real behavior. This could be considered in future studies and implemented in a field experiment or in the observation of real purchase behavior if enough bio-based products are available on the markets of apparel.

This study supports the development of new green apparel based on consumer preferences (e.g., with respect to type and content of fiber, origin of the biomass, certificates) and in particular, pricing of bio-based apparel. It shows that almost $40 \%$ of German consumers would make compromises with respect to the prices of bio-based apparel. However, it is highly relevant that the factors supporting assignment to price preference groups are also taken into account when marketing such products. These findings also relate to previous findings of Hustvedt and Bernard (2008) and Scherer et al. (2018b).

This research contributes to the development of sustainable supply chains for the production of green apparel. Supply chain managers in procurement, sales and production will benefit from the findings of this study. Similar to studies by (Imran et al., 2020; Jemai et al., 2020; Tayyab et al., 2020; Habib et al., 2021), it is possible to develop an importance classification for customers and suppliers in a supply chain for bio-based apparel.

Industries in the textile business and in the supply chains of textiles can use the insights of this study to define consumer groups interested in green or bio-based apparel as well as their motivations and behavior. The results of the CBC segmentation experiment supports product design of related apparel but also organizing the supply chains for the type of biomass used or the country of origin of the biomass raw material. Additionally, they show that interested consumer groups for green or biobased apparel have high expectations with respect to labeling of such products that should not only be free of pollutants but also incorporate a climate protection as well as a fair trade and fair production label.
Only if the explicit expectations of interested consumers of green or bio-based apparel can be fulfilled by textile companies, such consumers will be willing to pay a price premium for such products. This can be supported by information and communications strategies for related products that are touching the main motivations of interested consumer groups, such as green consumer values, altruism or positive attitudes toward bioplastics products and additionally include the aspect of subjective norms (i.e., influence of persons who are close to the recipient) in the communication strategy. Since consumers are also motivated to consume bio-based products after having product experiences with them, companies wishing to introduce bio-based apparel to the market should aim at launching not just a single product, but at least a small range of such apparel. A broader range of bio-based apparel offered by a company will also increase opportunities of being listed in relevant retail chains selling such apparel. Overall, the study shows that there are market opportunities for green or bio-based apparel, including the possibility of getting higher prices paid by at least some consumers in Germany. Thus, the insights of this study support the textile industry to realize these business opportunities in the coming years.

\section{DATA AVAILABILITY STATEMENT}

The datasets presented in this article are not readily available because confidality reasons. Requests to access the datasets should be directed to Klaus Menrad, klaus.menrad@hswt.de.

\section{ETHICS STATEMENT}

Ethical review and approval was not required for the study on human participants in accordance with the local legislation and institutional requirements. The patients/participants provided their written informed consent to participate in this study.

\section{AUTHOR CONTRIBUTIONS}

FS: conceptualization, methodology, software, validation, formal analysis, investigation, writing-original draft, writing-review and editing, and visualization. AE-K: conceptualization. KM: conceptualization, writing-review and editing, supervision, project administration, and funding acquisition. All authors contributed to the article and approved the submitted version.

\section{FUNDING}

This research, entitled New pathways, strategies, business, and communication models for bioplastics as a building block of a sustainable economy was funded by the German Government and the Federal Ministry of Education and Research (BMBF). The body responsible for the project was the German Aerospace Center (DLR) (support code for the project: 01UT1430C). 


\section{REFERENCES}

Ajzen, I., and Fishbein, M. (1980). Understanding Attitudes and Predicting Social Behavior. Englewood Cliffs, NJ:Prentice-Hall.

Aschemann-Witzel, J., and Zielke, S. (2017). Can't buy me green? A review of consumer perceptions of and behavior toward the price of organic food. $J$. Consumer Affairs 51, 211-251. doi: 10.1111/joca.12092

Austgulen, M. H. (2016). Environmentally sustainable textile consumption-what characterizes the political textile consumers? J. Consumer Policy 39, 441-466. doi: 10.1007/s10603-015-9305-5

Backhaus, K., Erichson, B., Plinke, W., and Weiber, R. (2000). "Diskriminanzanalyse," in Multivariate Analysemethoden (Berlin; Heidelberg: Springer Gabler), 145-224. doi: 10.1007/978-3-662-46076-4

Balster, T. (2019). Grüner Knopf - Was bringt das Siegel für nachhaltige Mode? Wird es damit leichter, nachhaltige Mode zu kaufen? Available online at: https://www.welt.de/icon/mode/article198598723/Gruener-KnopfWas-bringt-das-Siegel-fuer-nachhaltige-Mode.html

Batson, C. D., and Powell, A. A. (2003). "Altruism and prosocial behavior," in Handbook of Psychology: Personality and Social Psychology, Vol. 5, eds T. Millon and M. J. Lerner (John Wiley \& Sons, Inc.), 463-484. doi: 10.1002/0471264385.wei0519

Behe, B. K., Campbell, B. L., Hall, C. R., Khachatryan, H., Dennis, J. H., and Yue, C. (2013). Consumer preferences for local and sustainable plant production characteristics. HortScience 48, 200-208. doi: 10.21273/HORTSCI.48. 2.200

Blesin, J. M., Klein, F., Emberger-Klein, A., Scherer, C., Menrad, K., and Möhring, W. (2017). Bevölkerungsrepräsentative Online-Befragung in Deutschland $z u$ Biokunststoffen: Arbeitsbericht Oktober 2017. University of Applied Sciences Hannover, University of Applied Sciences Weihenstephan-Triesdorf. Available online at: http://biokunststoffe-nachhaltig.de/files/Downloads/BiNa \%20Working\%20Paper\%20zur\%20Bevoelkerungsbefragung\%202016.pdf

Borin, N., Cerf, D. C., and Krishnan, R. (2011). Consumer effects of environmental impact in product labeling. J. Consumer Market. 28, 76-86. doi: $10.1108 / 07363761111101976$

Brand, B. M., and Rausch, T. M. (2020). Examining sustainability surcharges for outdoor apparel using adaptive choice-based conjoint analysis. J. Clean. Prod. 289:125654. doi: $10.1016 /$ j.jclepro.2020.125654

Buxel, H. (2010). Akzeptanz und Nutzung von Nährwertkennzeichnung auf Lebensmitteln durch Konsumenten: Ergebnisse einer empirischen Untersuchung unter Berücksichtigung der GDA- und Ampel-Nährwertkennzeichnung. Münster: University of Applied Sciences Münster. Available online at: https:// www.vzbv.de/sites/default/files/downloads/naehrwertkennzeichnung_studie_ fh_muenster_03_2010.pdf

Casimir, G., and Dutilh, C. (2003). Sustainability: a gender studies perspective Int. J. Consumer Stud. 27, 316-325. doi: 10.1046/j.1470-6431.2003. 00323.x

Chekima, B., Syed Khalid Wafa, S. A. W., Igau, O. A., Chekima, S., and Sondoh, S. L. (2016). Examining green consumerism motivational drivers: does premium price and demographics matter to green purchasing? J. Clean. Prod. 112, 3436-3450. doi: 10.1016/j.jclepro.2015.09.102

Choi, Y., Chen, K.-J., and Marsh, T. L. (2020). Consumer preference for bio-based batteries. J. Consumer Behav. 19, 382-396. doi: 10.1002/cb.1827

Chrobot, P., Faist, M., Gustavus, L., Martin, A., Stamm, A., Zah, R., et al. (2018). Measuring Fashion: Environmental Impact of the Global Apparel and Footwear Industries Study [Full Report and Methodological Considerations]. Quantis. Available online at: https:/quantis-intl.com/wp-content/uploads/2018/03/ measuringfashion_globalimpactstudy_full-report_quantis_cwf_2018a.pdf

CO Data (2018). Volume and Consumption: How Much Does The World Buy? Available online at: https://www.commonobjective.co/article/volumeand-consumption-how-much-does-the-world-buy

Diamantopoulos, A., Schlegelmilch, B. B., Sinkovics, R. R., and Bohlen, G. M. (2003). Can socio-demographics still play a role in profiling green consumers? A review of the evidence and an empirical investigation. J. Bus. Res. 56, 465-480. doi: 10.1016/S0148-2963(01)00241-7

Eggers, F., and Sattler, H. (2011). Preference measurement with conjoint analysis. Overview of state-of-the-art approaches and recent developments. GfK Market. Intell. Rev. 3, 36-47. doi: 10.2478/gfkmir-2014-0054
Englis, B. G., and Phillips, D. M. (2013). Does innovativeness drive environmentally conscious consumer behavior? Psychol. Market. 30, 160-172. doi: 10.1002/mar.20595

Euratex (2019). Data \& Statistics. The Euratex, the European Apparel and Textile Industry. Available online at: https://euratex.eu/eu-apparel-textilesector/statistics/

Evans, J. R., and Mathur, A. (2005). The value of online surveys. Internet Res. 15, 195-219. doi: $10.1108 / 10662240510590360$

Fashion United (2017). Global Fashion Industry Statistics: International Apparel. Available online at: https://fashionunited.com/global-fashion-industrystatistics/

Fuhr, L., Buschmann, R., and Freund, J. (2019). Plastikatlas: Daten und Fakten über eine Welt voller Kunststoff. Heinrich-Böll-Stiftung. Available online at: https:// www.boell.de/de/plastikatlas

German Federal Statistical Office (2015). Mikrozensus. Statistisches Bundesamt. Mikrozensus. Available online at: https://www.destatis.de/

Grimm, P. (2010). "Social desirability bias," in Wiley International Encyclopedia of Marketing. doi: 10.1002/9781444316568.wiem02057

Habib, M. S., Asghar, O., Hussain, A., Imran, M., Mughal, M. P., and Sarkar, B. (2021). A robust possibilistic programming approach toward animal fat-based biodiesel supply chain network design under uncertain environment. J. Clean. Prod. 278:122403. doi: 10.1016/j.jclepro.2020.122403

Hartmann, P., and Apaolaza-Ibáñez, V. (2012). Consumer attitude and purchase intention toward green energy brands: the roles of psychological benefits and environmental concern. J. Bus. Res. 65, 1254-1263. doi: 10.1016/j.jbusres.2011.11.001

Haws, K. L., Winterich, K. P., and Naylor, R. W. (2014). Seeing the world through GREEN-tinted glasses: green consumption values and responses to environmentally friendly products. J. Consumer Psychol. 24, 336-354. doi: $10.1016 /$ j.jcps.2013.11.002

Hefner, D. (2013). “Wie kriegen wir sie ins Boot?" Eine Typologie zur Entwicklung von Kommunikationsstrategien zur Förderung umweltschützenden Verhaltens. Med. Kommun. 61, 387-405. doi: 10.5771/1615-634x-2013-3-387

Herbes, C., Beuthner, C., and Ramme, I. (2018). Consumer attitudes towards biobased packaging-a cross-cultural comparative study. J. Clean. Prod. 194, 203-218. doi: 10.1016/j.jclepro.2018.05.106

Hess, S., Shires, J., and Jopson, A. (2013). Accommodating underlying proenvironmental attitudes in a rail travel context: application of a latent variable latent class specification. Transport. Res. D Transport Environ. 25, 42-48. doi: 10.1016/j.trd.2013.07.003

Hustvedt, G., and Bernard, J. C. (2008). Consumer willingness to pay for sustainable apparel: the influence of labelling for fibre origin and production methods. Int. J. Consumer Stud. 32, 491-498. doi: 10.1111/j.1470-6431.2008.00706.x

Hustvedt, G., and Dickson, M. A. (2009). Consumer likelihood of purchasing organic cotton apparel. J. Fashion Market. Manage. 13, 49-65. doi: $10.1108 / 13612020910939879$

IBM Corp. (2015). IBM SPSS 23 Statistics for Windows (Version Version 23.0) [Computer Software]. Armonk, NY: IBM Corp. Available online at: https:// www.ibm.com/support/pages/downloading-ibm-spss-statistics-23

Imran, M., Agha, M. H., Ahmed, W., Sarkar, B., and Ramzan, M. B. (2020). Simultaneous customers and supplier's prioritization: an AHP-based fuzzy inference decision support system (AHP-FIDSS). Int. J. Fuzzy Syst. 22, 2625-2651. doi: 10.1007/s40815-020-00977-9

Jansson, J. (2011). Consumer eco-innovation adoption: assessing attitudinal factors and perceived product characteristics. Bus. Strat. Environ. 20, 192-210. doi: 10.1002/bse. 690

Jemai, J., Chung, B. D., and Sarkar, B. (2020). Environmental effect for a complex green supply-chain management to control waste: a sustainable approach. J. Clean. Prod. 277:122919. doi: 10.1016/j.jclepro.2020.122919

Joshi, Y., and Rahman, Z. (2015). Factors affecting green purchase behaviour and future research directions. Int. Strat. Manage. Rev. 3, 128-143. doi: $10.1016 /$ j.ism.2015.04.001

Kainz, U. (2016). Consumers' Willingness to Pay for Durable Biobased Plastic Products: Findings from an Experimental Auction. Technische Universität München. Available online at: http://nbn-resolving.de/urn/resolver.pl?urn: nbn:de:bvb:91-diss-20161111-1293618-1-5 
Kaiser, F. G., Ranney, M., Hartig, T., and Bowler, P. A. (1999). Ecological behavior, environmental attitude, and feelings of responsibility for the environment. Eur. Psychol. 4:59. doi: 10.1027//1016-9040.4.2.59

Klein, F., Emberger-Klein, A., Menrad, K., Möhring, W., and Blesin, J. M. (2019). Influencing factors for the purchase intention of consumers choosing bioplastic products in Germany. Sustain. Prod. Consum. 19, 33-43. doi: 10.1016/j.spc.2019.01.004

Klein, F. F., Emberger-Klein, A., and Menrad, K. (2020). Indicators of consumers' preferences for bio-based apparel: a German case study with a functional rain jacket made of bioplastic. Sustainability 12:675. doi: 10.3390/su12020675

Klein, H. (2019). Nachhaltigkeit: Mode-Wahnsinn zerstört Umwelt - wie wir das ändern. FOCUS-Online. Available online at: https://www.focus.de/ perspektiven/nachhaltigkeit/nachhaltigkeit-mode-wahnsinn-zerstoertumwelt-wie-wir-das-aendern_id_10964545.html

Koszewska, M. (2013). A typology of P olish consumers and their behaviours in the market for sustainable textiles and clothing. Int. J. Consumer Stud. 37, 507-521. doi: $10.1111 / \mathrm{ijcs} .12031$

Kurka, S. (2012). Biomasse-basierte Produkte aus Konsumentensicht: Ausgewählte europäische Länder im Vergleich. Available online at: http://nbn-resolving.de/ urn/resolver.pl?urn:nbn:de:bvb:91-diss-20120711-1086928-1-7

Laroche, M., Bergeron, J., and Barbaro-Forleo, G. (2001). Targeting consumers who are willing to pay more for environmentally friendly products. J. Consumer Market. 18, 503-520. doi: 10.1108/EUM0000000006155

Lee, Y. J., de Young, R., and Marans, R. W. (1995). Factors influencing individual recycling behavior in office settings. Environ. Behav. 27, 380-403. doi: $10.1177 / 0013916595273006$

Leinfelder, B., and Regensburger, F. (2019). Jugendliche aus Friedberg erfindet Filter für Mikroplastik. Bayerischer Rundfunk. Mittags in Schwaben. Available online at: https://www.br.de/nachrichten/bayern/jugendliche-aus-friedberg-erfindetfilter-fuer-mikroplastik, RVcMGgf

Louviere, J. J., and Woodworth, G. (2018). Design and analysis of simulated consumer choice or allocation experiments: an approach based on aggregate data. J. Market. Res. 20, 350-367. doi: 10.1177/002224378302000403

Lusk, J. L., Nilsson, T., and Foster, K. (2007). Public preferences and private choices: effect of altruism and free riding on demand for environmentally certified pork. Environ. Resour. Econ. 36, 499-521. doi: 10.1007/s10640-006-9039-6

Lynch, D. H. J., Klaassen, P., and Broerse, J. E. W. (2017). Unraveling Dutch citizens' perceptions on the bio-based economy: the case of bioplastics, bio-jetfuels and small-scale bio-refineries. Ind. Crops Prod. 106, 130-137. doi: 10.1016/j.indcrop.2016.10.035

McDonald, S., Oates, C., Thyne, M., Alevizou, P., and McMorland, L. A. (2009). Comparing sustainable consumption patterns across product sectors. Int. J. Consumer Stud. 33, 137-145. doi: 10.1111/j.1470-6431.2009.00755.x

McFadden, D. (1986). The choice theory approach to market Research. Market. Sci. 5, 275-297. doi: 10.1287/mksc.5.4.275

Milfont, T. L. (2009). The effects of social desirability on self-reported environmental attitudes and ecological behaviour. Environmentalist 29, 263-269. doi: 10.1007/s10669-008-9192-2

Mishra, D., Akman, I., and Mishra, A. (2014). Theory of reasoned action application for green information technology acceptance. Comput. Hum. Behav. 36, 29-40. doi: 10.1016/j.chb.2014.03.030

Morrison, D. G. (1979). Purchase intentions and purchase behavior. J. Market. 43:65. doi: $10.2307 / 1250742$

Muthu, S. S. (2014). Roadmap to Sustainable Textiles and Clothing: Eco-Friendly Raw Materials, Technologies, and Processing Methods. Singapore:Springer.

Nam, C., Dong, H., and Lee, Y. A. (2017). Factors influencing consumers' purchase intention of green sportswear. Fashion Textiles 4:179. doi: 10.1186/s40691-017-0091-3

Niedermeier, A., Emberger-Klein, A., and Menrad, K. (2021). Which factors distinguish the different consumer segments of green fast-moving consumer goods in Germany? Bus. Strat. Environ. 36:360. doi: 10.1002/bse.2718

Niinimäki, K. (2010). Eco-clothing, consumer identity and ideology. Sustain. Dev. 18, 150-162. doi: 10.1002/sd.455

Osburg, V. S., Strack, M., and Toporowski, W. (2016). Consumer acceptance of Wood-Polymer Composites: a conjoint analytical approach with a focus on innovative and environmentally concerned consumers. J. Clean. Prod. 110, 180-190. doi: 10.1016/j.jclepro.2015. 04.086
Pfattheicher, S., Sassenrath, C., and Schindler, S. (2016). Feelings for the suffering of others and the environment. Environ. Behav. 48, 929-945. doi: $10.1177 / 0013916515574549$

Price, L. L., Feick, L. F., and Guskey, A. (2018). Everyday market helping behavior. J. Public Policy Market. 14, 255-266. doi: 10.1177/07439156950140 0207

Rana, S., Pichandi, S., Parveen, S., and Fangueiro, R. (2014). "Biosynthetic fibers: production, processing, properties and their sustainability parameters," in Textile Science and Clothing Technology. Roadmap to Sustainable Textiles and Clothing, Vol. 46, ed S. S. Muthu (Singapore:Springer), 109-138. doi: 10.1007/978-981-287-065-0_4

Rumm, S. (2016). Verbrauchereinschätzungen zu Biokunststoffen: eine Analyse vor dem Hintergrund des heuristic-systematic model. Available online at: http://nbnresolving.de/urn/resolver.pl?urn:nbn:de:bvb:91-diss-20161215-1306582-1-8

Rumm, S., Klein, A., Zapilko, M. A., and Menrad, K. (2013). "Labelling for biobased plastics," in First International Conference on Resource Efficiency in Interorganizational Networks: ResEff 2013; November 13th-14th, 2013 (Göttingen: Georg-August-Universität Göttingen, Univ.-Verl. Göttingen), 403-414.

Šajn, N. (2019). Environmental Impact of the Textile and Clothing Industry: What Consumers Need to Know. European Parliamentary Research Service. Available online at: http://www.europarl.europa.eu/RegData/etudes/BRIE/2019/633143/ EPRS_BRI(2019)633143_EN.pdf

Sanad, R. A. (2016). Consumer attitude and purchase decision towards textiles and apparel products. World J. Textile Eng. Technol. 2, 16-30.

Sawtooth Software Inc. (2004). The CBC Latent Class: Version 3. Technical Paper Series. Available online at: https://sawtoothsoftware.com/resources/technicalpapers/latent-class-technical-paper

Sawtooth Software Inc. (2015). SSI Web 8 (Version 8.4.8) [Computer Software]. Orem, UT: Sawtooth Software Inc.

Scherer, C., Emberger-Klein, A., and Menrad, K. (2017). Biogenic product alternatives for children: consumer preferences for a set of sand toys made of bio-based plastic. Sustain. Prod. Consum. 10, 1-14. doi: 10.1016/j.spc.2016.11.001

Scherer, C., Emberger-Klein, A., and Menrad, K. (2018a). Consumer preferences for outdoor sporting equipment made of bio-based plastics: results of a choice-based-conjoint experiment in Germany. J. Clean. Prod. 203, 1085-1094. doi: 10.1016/j.jclepro.2018.08.298

Scherer, C., Emberger-Klein, A., and Menrad, K. (2018b). Segmentation of interested and less interested consumers in sports equipment made of bio-based plastic. Sustain. Prod. Consum. 14, 53-65. doi: 10.1016/j.spc.2018.01.003

Schleenbecker, R., and Hamm, U. (2013). Consumers' perception of organic product characteristics. A review. Appetite, 71, 420-429. doi: 10.1016/j.appet.2013.08.020

Stern, P. C., Dietz, T., and Kalof, L. (1993). Value orientations, gender, and environmental concern. Environ. Behav. 25, 322-348. doi: $10.1177 / 0013916593255002$

Straughan, R. D., and Roberts, J. A. (1999). Environmental segmentation alternatives: a look at green consumer behavior in the new millennium. $J$. Consumer Market. 16, 558-575. doi: 10.1108/07363769910297506

Tanner, C., and Wölfing Kast, S. (2003). Promoting sustainable consumption: determinants of green purchases by Swiss consumers. Psychol. Market. 20, 883-902. doi: 10.1002/mar.10101

Tarkiainen, A., and Sundqvist, S. (2005). Subjective norms, attitudes and intentions of Finnish consumers in buying organic food. Br. Food J. 107, 808-822. doi: 10.1108/00070700510629760

Tayyab, M., Jemai, J., Lim, H., and Sarkar, B. (2020). A sustainable development framework for a cleaner multi-item multi-stage textile production system with a process improvement initiative. J. Clean. Prod. 246:119055. doi: 10.1016/j.jclepro.2019.119055

Tellis, G. J., Yin, E., and Bell, S. J. (2009). Global consumer innovativeness: crosscountry differences and demographic commonalities. SSRN Electron. J. 17, 1-22. doi: 10.2139/ssrn.1335551

Temme, J. (2009). "Discrete-choice-modelle," in Methodik der empirischen Forschung, eds S. Albers, D. Klapper, U. Konradt, A. Walter, and J. Wolf (Wiesbaden:Gabler Verlag), 299-314. doi: 10.1007/978-3-322-96406-9_20

Teng, Y. M., Wu, K. S., and Liu, H. H. (2015). Integrating altruism and the theory of planned behavior to predict patronage intention of a green hotel. J. Hosp. Tourism Res. 39, 299-315. doi: 10.1177/1096348012471383 
Textile Exchange (2017). What Are Biosynthetics? Textile Exchange. Available online at: https://aboutbiosynthetics.org/

UNECE (2018). UN Alliance Aims to Put Fashion on Path to Sustainability. Available online at: https://unece.org/forestry/press/un-alliance-aims-putfashion-path-sustainability

UNFCCC (2018). Fashion Industry, UN Pursue Climate Action for Sustainable Development. Available online at: https://unfccc.int/news/fashion-industryun-pursue-climate-action-for-sustainable-development

Untaru, E. N., Ispas, A., Candrea, A. N., Luca, M., and Epuran, G. (2016). Predictors of individuals' intention to conserve water in a lodging context: the application of an extended theory of reasoned action. Int. J. Hosp. Manag. 59, 50-59. doi: 10.1016/j.ijhm.2016.09.001

Young, R. de (2000). New ways to promote proenvironmental behavior: expanding and evaluating motives for environmentally responsible behavior. J. Soc. Issues 56, 509-526. doi: 10.1111/0022-4537.00181

Young, W., Hwang, K., McDonald, S., and Oates, C. J. (2009). Sustainable consumption: green consumer behaviour when purchasing products. Sustain. Dev. 18, 20-31. doi: 10.1002/sd.394
Yue, C., Hall, C. R., Behe, B. K., Campbell, B. L., Dennis, J. H., and Lopez, R. G. (2010). Are Consumers Willing to Pay More for Biodegradable Containers Than for Plastic Ones? Evidence From Hypothetical Conjoint Analysis and Nonhypothetical Experimental Auctions (Agricultural and Applied Economics Association (AAEA) Conferences). Denver, CO: Agricultural and Applied Economics Association (AAEA). doi: 10.22004/ag.econ.60968

Conflict of Interest: The authors declare that the research was conducted in the absence of any commercial or financial relationships that could be construed as a potential conflict of interest.

Copyright (C) 2021 Stahl, Emberger-Klein and Menrad. This is an open-access article distributed under the terms of the Creative Commons Attribution License (CC BY). The use, distribution or reproduction in other forums is permitted, provided the original author(s) and the copyright owner(s) are credited and that the original publication in this journal is cited, in accordance with accepted academic practice. No use, distribution or reproduction is permitted which does not comply with these terms. 


\section{APPENDICES}

TABLE A1 | CBC introductory text.

First, please put yourself in the following situation:

You want to buy a new rain jacket. You are looking for a high-quality product

from a brand you know in an outdoor clothing store. After a short search,

you will find what you are looking for and have the choice between different

alternatives. The size, color, cut and function of the jacket meet your

expectations. The seller points out that some jackets are made from

bioplastics. He goes on to say that various renewable raw materials were

used for its production instead of petroleum, but that no impairment of

product quality is to be expected. He advises you further that the raw

materials come from different countries of origin and that there are also

various certifications on the rain jackets, which give information on the

production and material of functional apparel.

TABLE A2 | Choice set (example for random task).

\begin{tabular}{|c|c|c|c|c|}
\hline & Alternative 1 & Alternative 2 & 2 Alternative 3 & Alternative 3 \\
\hline $\begin{array}{l}\text { Percentage of } \\
\text { bioplastic }\end{array}$ & f 100\% & $20 \%$ & $50 \%$ & $\begin{array}{l}\text { NONE: } \\
\text { I would not choose } \\
\text { any of these. }\end{array}$ \\
\hline Raw material & Sugar cane & Potatoes & Indian maize & \\
\hline $\begin{array}{l}\text { Origin of } \\
\text { resource }\end{array}$ & USA & Asia & EU & \\
\hline Certification & Free of pollutants & s No certificate & Fair production & \\
\hline \multirow[t]{2}{*}{ Price } & $239 €$ & $349 €$ & $109 €$ & \\
\hline & $\circ$ & $\circ$ & $\circ$ & $\circ$ \\
\hline
\end{tabular}

